\title{
In de voetsporen van de Boeddha
}

\author{
Mano de Kok
}

Published online: 4 augustus 2021

(C) Bohn Stafleu van Loghum is een imprint van Springer Media B.V., onderdeel van Springer Nature 2021

Als een olievlek verspreidt het virus zich over de wereld [1]. Nee, ik heb het niet over het coronavirus, maar over het spirituele virus. Ja, je leest het goed, en dat virus doet nu ook zijn intrede in de podotherapie. Uit onderzoek blijkt dat een kwart van alle mensen in Nederland, waaronder ikzelf, zich spiritueel noemt. Maar wat denken die mensen dan die zichzelf spiritueel noemen en nog belangrijker, hebben zij een andere aanpak nodig in jouw praktijkruimte?

Misschien is dit al meteen een trigger voor je, hetzij positief, hetzij negatief, afhankelijk van de richting waarin je op het woord spiritualiteit bent geconditioneerd. Want, laten we eerlijk wezen, spiritualiteit is een containerbegrip geworden voor alles wat te maken heeft met yoga, mindfulness, tarotkaarten leggen, pendelen, mediteren, je ware zelf ontdekken, knuffelen met varkens en zo kan ik nog wel even doorgaan. Wees niet bang, ik ga mezelf hier echt niet verbinden aan zweverige toestanden en vervolgens het spirituele zwarte schaap van de podotherapie worden. Wel wil ik in deze column onderwerpen aanroeren die raken aan ons domein en je visie uitdagen, maar of je die visie nu bijstelt of juist behoudt, alles is oké.

Voor mij is spiritualiteit het onderzoeken van je geest, Engelsen zeggen mind, en de werkelijkheid ervaren zoals zij is, zoals een wetenschapper de werkelijkheid inventariseert. Het woord mindful vertalen in het Nederlands is een uitdaging. Ik denk dat 'bedachtzaamheid' voor mij nog het meeste in de buurt komt.

Onze hersenen zijn eraan gewend geraakt de hele dag na te denken over wat er is gebeurd in het verleden of mogelijk nog gaat gebeuren in de toekomst. Zodra je je afvraagt wat je op een bepaald moment, het 'nu', ervaart in je lichaam, doorbreek je deze onwillekeurige gedachtestroom. Mensen die veel stress ervaren, zijn vaak overmatige denkers. Ook angst kan voortkomen uit nadenken over iets dat mogelijk in de toekomst gaat gebeuren.

Mindful walking of running is een van de manieren om die automatische gedachtestroom te doorbreken: lopen met je aandacht bij datgene wat je lichaam ervaart op dat moment [2]. Dat is meditatief bezig zijn.

Krijg jij mensen in je praktijk die aan 'mindful lopen’ doen? Dan dragen ze waarschijnlijk een spirituele bril. Deze groep zal wellicht minder graag blijvende hulpmiddelen gebruiken dan een hedonist of humanist. Ze zijn vaak meer op zoek naar de reden achter hun fysieke probleem en vragen of ze het probleem ook met voetoefeningen kunnen oplossen. Verantwoordelijkheid nemen voor het probleem en daarbij geholpen worden. En daar moet jij als podotherapeut je rol in pakken.

\section{Literatuur}

1. Ganzevoort R. Universiteit van Nederland. Wordt iedereen spiritueel als religies verdwijnen?. https:/ / www.youtube. com/watch?v=_SSFiWpJUac (Gecreëerd: 26 jan 2016). Geraadpleegd op: 15 jun 2021.

2. Edwards MK, Rosenbaum S, Loprinzi PD. Differential experimental effects of a short bout of walking, meditation, or combination of walking and meditation on state anxiety among young adults. Am J Health Promot. 2018;32(4):949-58.

Mano de Kok, podotherapeut, algemeen directeur Halluxgroep

\section{M. de Kok ( $ه)$}

Hallux Voetexperts, Breda, Nederland

mano@hallux-groep.nl 